\title{
Изучение транскрипционной активности последовательности CR523443 в зависимости от генотипа кур породы русская белая
}

Баркова О. Ю., кандидат биологических наук, старший научный сотрудник

Вахрамеев А.Б., старший научный сотрудник

Всероссийский научно-исследовательский институт генетики и разведения сельскохозяйственных животных (ВНИИГРЖ) филиал ФГБНУ «Федеральный научный центр животноводства - ВИЖ имени академика Л.К. Эрнста»

\begin{abstract}
Аннотащия: Ряд предшествующих исследований Выябил мононуклеотидную замену 2_l последовательности CR523443, достоверно влияющую на такие признаки, как масса яйца, толщина и упругая десрормация скорлупы. Целью данной работы было проберить транскрипиионную актибность последовательности CR523443 в забисимости от генотипа кур по данной замене и оценить сбязь уровня ее экспрессии с изменчибостью признаков яйца у кур породы русская белая. Анализ экспрессии последовательности CR523443 6 яйцебодах показал значительно пониженный ее уровень, 6 отличие от уробня экспрессии 6 матке тех же особей. Экспрессия последовательности CR523443 6 боронке яйцебода у кур с генотипом TT состабила 0,54, а с генотипом CT - 0,15. Экспрессия последовательности CR523443 6 матке кур с генотипом TT была выше 649 раз, чем у курицы с генотипом СС (бзятой как контроль), а с генотипом CT - 611 раз (отличия статистически недостоверны). Полученные данные согласуются с предыдущим ассоциативным анализом сбязи признакоб яйца с генотипом, где наибольшую толщину скорлупы и наименьиую упругую деформацию скорлупы имели гомозиготные куры $\Pi$, а наименьиую толщину и наибольшую упругую десормацию скорлупы яйца - куры с генотипом СС.
\end{abstract}

Ключебые слова: куры, экспрессия генов, мононуклеотидный полиморфизм (SNP), качество яии,, скорлупа яии, масса скорлупы.

Введение. Промышленно выращиваемые куры вместе с другими видами домашней птицы стали ключевым объектом для производства легкодоступного животного белка. Увеличение отечественного производства качественных продуктов питания имеет решающее значение для населения страны. За последние 50 лет селекция, начавшаяся сначала на уровне породы, а затем с использованием количественной генетики в сочетании со сложной системой разведения, привела к созданию высокопродуктивной гибридной птицы, отселекционированной по множеству признаков, связанных с произ- водством яиц [1]. Качество яйца и яйценоскость кур относятся к количественным признакам, контролируемым множеством генов; но основное внимание селекционеров занимает поиск мажорных и казуальных мононуклеотидных полиморфизмов, оказывающих наибольшее влияние на проявление хозяйственно полезных признаков. Данные мононуклеотидные замены могут успешно быть использованы в маркерной селекции птицы.

В предшествующие годы проведен ряд исследований по поиску значимых мутаций, оказывающих влияние на признаки качества яйца. В 4-й хромосоме ку- рицы рядом с микросателлитом MCW0114 был картирован локус количественного признака (QTL), влияющий на толщину скорлупы яиц [2]. С помощью метода экспрессирующих последовательностей ДНК (EST) в ближайшем окружении микросателлита MCW0114 был обнаружен транскрипт - клон ChEST985k21, экспрессия которого коррелировала с толщиной скорлупы кур польской породы зеленоногая куропатчатая [3]. В результате секвенирования ChEST985k21 в соответствующей нуклеотидной последовательности CR523443 были выявлены шесть мононуклеотидных замен (SNP). Наиболее достоверная ас- 
социация мононуклеотидной замены с толщиной скорлупы была установлена для SNP 2_1 [4].

Олигонуклеотидный полиморфизм SNP 2_1 был обнаружен на расстоянии 900 п.н 5' - 3' направлении от конца транскрибируемой последовательности CR523443, состоящей из 2105 пар нуклеотидов, расположенной на GGA4 в положении 16,7 Мб. Рядом с изучаемой нуклеотидной последовательностью находятся следующие гены: COMMD5, FAM199x, RHOXF1 [5]. Построение карты неравновесия по сцеплению для выявления района 4-й хромосомы, в котором локализуется SNP 2_1, показал высокий уровень неравновесия по сцеплению между SNP 2_1 и FAM199X у линии 72 породы род-айленд $(0,962)$ и у кросса CD $(0,88)$. Из полученных данных следует, что наиболее вероятным кандидатом, влияющим на признаки яйца, является ген FAM 199X. Он принадлежит к семейству 199 генов, связанных с X-хромосомой; у курицы данный ген не был изучен [6].

При проведении статистического анализа данных для трех генотипов мононуклеотидной замены SNP 2_1 (СТ, СС и ТТ) у 137 кур популяции аврора достоверная ассоциация получена для признаков упругая деформация $(\mathrm{P}<0.001)$ и толщина скорлупы яйца $(\mathrm{P}<0.001)$. Эффект замещения аллелей произведен с поправкой Бонферрони, где замена СС на ТТ для признака толщина яичной скорлупы $(\mathrm{P}<0,001)$ составил 33,7 мкм, СТ на СС 26,1 мкм $(\mathrm{P}<0,003)$, ТТ на СТ 7,6 мкм ( $><0,001)$. Эфрфект замещения аллелей СТ на СС для признака упругой деформации составил 2,7 мм ( $<<0,002)$, СТ на ТТ 4,8 мм $(\mathrm{P}<0,0001)$, СТ на СС 2,0 мм
( $\mathrm{P}=0,006)$ [7]. Данная замена в последовательности CR523443 также показала достоверное различие генотипов по признакам масса яйца, упругая деформация и толщина скорлупы $(\mathrm{P}<0,001)$ у породы род-айленд красный (97 особей). Эффект замещения аллелей СТ-СС для признака толщина скорлупы составил 38,3 мкм, замены СС на ТТ 33,4 мкм (P<0,001). Для признака упругая деформация скорлупы эффект замещения аллелей СТ на ТТ составил 5,3 мм ( $<<0,001)$, СС на ТТ 4,0 мм $(\mathrm{P}<0,001)$. Эфффект замены аллелей для признака масса яйца наблюдался при замене СС-ТТ $(P<0,001)$ и составлял 1 г[7]. Достоверный эффект замены нуклеотидов SNP 2_1 у кур родайленд и аврора составил более одного стандартного отклонения. Таким образом, QTL, маркированный SNP 2_1 последовательности CR523443, можно отнести к мажорным QTL, поскольку его эффект составляет одну сигму; он оказывает плейотропный эффект на признаки качества яйца [7].

Целью данного исследования было проверить транскрипционную активность последовательности CR523443 в зависимости от генотипа кур по SNP 2_1 и оценить связь этой активности с изменчивостью признаков яйца, таких как упругая деформация и толщина скорлупы, у кур породы русская белая.

Материал и методика исследований. Для идентификации генотипов СT, TT, СT по SNP 2_1 последовательности CR523443 было отобрано 97 кур породы русская белая. Кровь брали из подкрыльцовой вены, ДНК выделяли при помощи фенольного метода. Куры были генотипированы с использованием двух аллель-спец- ифических праймеров для SNP 2_1, которые находится в положении -958 от CR523443 (2). Аллельспецифические прямой и обратный праймеры: С 5'СТССТСАСТG TCTTAGTCTGATCAGC3;'T5'СTGCT CAGTGTCTTAGTCTGATCAGT 3; Dn 5'ACAGTCATGATGAGGAAACAGG 3“. Амплификацию ДНК проводили с использованием амплификатоpa IQ-5 (Bio-Rad, США). Реакцию проводили в следующем режиме: $95^{\circ} \mathrm{C}-5$ мин.; $95^{\circ} \mathrm{C}-1$ мин., $60^{\circ} \mathrm{C}$ 1 мин., $72^{\circ} \mathrm{C}-1$ мин. (30 циклов); $72^{\circ} \mathrm{C}-7$ мин.; $7^{\circ} \mathrm{C}-\infty$. Полученные фрагменты ДНК разделяли методом электрофрореза в 1,5\% агарозном геле.

Для анализа уровня экспрессии всего было отобрано десять кур, включая 4 и 5 голов с генотипами ТТ и СТ соответственно. Генотип СС является редким, из 97 особей была выявлена только одна курица с этим генотипом. Выделение матричной РНК из ткани матки и яйцевода кур проводилось с помощью набора реактивов типа Aurum Total RNA Fatty and Fibrous Kit (Bio-Rad, США) в соответствие с рекомендациями производителя. Синтез однонитевой кДНК проводили при помощи набора iScript OneStep RT-PCR Kit (Bio-Rad, США), тщательно следуя указаниям производителя. Смесь для реакции включает 12,5 мкл 2xSYBR Green RT-PCR reaction mix (Bio-Rad, США), 1 мкл матричной РНК (20 нг), 1 мкл обратной транскриптазы pt reverse transcriptase for one-step RT-PCR (Bio-Rad, CШA), 8,5 мкл $\mathrm{H}_{2} \mathrm{O}$ и по 1 мкл 10 мкМ раствора каждого праймера. Конечный объем реакционной смеси составляет 25 мкл. Реакции проводили при помощи амплификатора QuantStudio 5 Real Time 
Таблица 1. Степень экспрессии последовательности CR523443 в тканях воронки яйцевода кур породь русская белая по методу сравнительной нормализации генотипа СС с генотипами СТ и TT

\begin{tabular}{|c|c|c|c|c|c|c|c|}
\hline № курицы & генотип & $\begin{array}{l}\text { Ct среднее } \\
\text { beta actin }\end{array}$ & $\begin{array}{c}\text { Ct среднее } \\
\text { GAPDH }\end{array}$ & $\begin{array}{c}\text { Ct среднее } \\
\text { CR523443 }\end{array}$ & $\Delta \mathrm{Ct}$ среднее & $\begin{array}{c}\Delta \Delta \mathrm{Ct}(\Delta \mathrm{Ct} 3- \\
\Delta \mathrm{Ct} 2-\Delta \mathrm{Ct} 1)\end{array}$ & $\begin{array}{c}2-\Delta \Delta C t) \\
R Q\end{array}$ \\
\hline 10 & CC & 12,68 & 9,9 & 10,249 & 0,465 & $\mathbf{0}$ & 1 \\
\hline 1 & $\mathrm{TT}$ & 12,978 & 13,30 & 13,455 & 0,313 & 0,445 & 0,735 \\
\hline 5 & $\mathrm{TT}$ & 11,713 & 11,407 & 11,429 & 0,132 & 1,078 & 0,474 \\
\hline 7 & $\mathrm{TT}$ & 12,494 & 10,014 & 12,075 & 1,638 & 0,661 & 0,661 \\
\hline 11 & $\mathrm{TT}$ & 11,89 & 10,23 & 13,338 & 2,623 & 1,77 & 0,293 \\
\hline Х среднее & & 12,26 & 11,24 & 12,57 & 1,17 & 0,99 & 0,54 \\
\hline 2 & $\mathrm{CT}$ & 12,394 & 10,25 & 13,936 & 2,615 & 2,74 & 0,149 \\
\hline 3 & $\mathrm{CT}$ & 12,194 & 12,07 & 16,229 & 4,095 & 4,227 & 0,053 \\
\hline 4 & $\mathrm{CT}$ & 11,377 & 12,181 & 12,725 & 0,946 & 1,147 & 0,452 \\
\hline 6 & $\mathrm{CT}$ & 11,954 & 9,468 & 11,726 & 1,015 & 10,00 & 0,001 \\
\hline 8 & $\mathrm{CT}$ & 11,925 & 8,33 & 13,388 & 3,258 & 3,39 & 0,095 \\
\hline X среднее & & 11,96 & 10,45 & 13,6 & 2,38 & 4,3 & 0,15 \\
\hline
\end{tabular}

PCR System (Applied Biosystems by. ThermoFisher Scientific) в следующем режиме: $95^{\circ} \mathrm{C}$ - 5 мин. (40 циклов); $95^{\circ} \mathrm{C}$ - 10 сек; $55^{\circ} \mathrm{C}$ - 10 сек; $72^{\circ} \mathrm{C}$ - 15 сек. В качестве реферативного гена использовались гены GAPDH (глицеральдегид-3-фосфат дегидрогеназы) домашней курицы (имеющий идентификационный номер NM_204305) и бета-актина (NM_205518). Для данных генов взяты следующие последовательности праймеров: GAPDHfw, 5'-GGGCTCATCTGAAGGGTGGTGCTA-3; GAPDHrv, 5'-GTGGGGGAGACAGAAGGGAACAGA-3'. Beta actin fw 5'-CGCCCCGGCTCTGACTGACC-3' Beta actin rv 5'-CCTCGGGGCACCTGAACCTCTC-3'.

Для вычисления относительных количеств амплифициру- емых последовательностей использован метод $2 \Delta \Delta \mathrm{Ct}$ (Livak K.J. и др., 2001). Достоверность различий средних значений уровней экспрессии в 3 группах оценивали при помощи t-критерия Стьюдента. Статистическая обработка полученных результатов осуществлена с помощью автоматической программы, предусмотренной амплификатором QuantStudio 5 Real Time PCR System.

\section{Результаты исследований} и их и обсуждение. Анализ экспрессии в яйцеводах 10 кур (рис. 1, табл. 1) показал значительно пониженный уровень экспрессии последовательности CR523443, в отличие от уровня экспрессии в матке тех же осо-

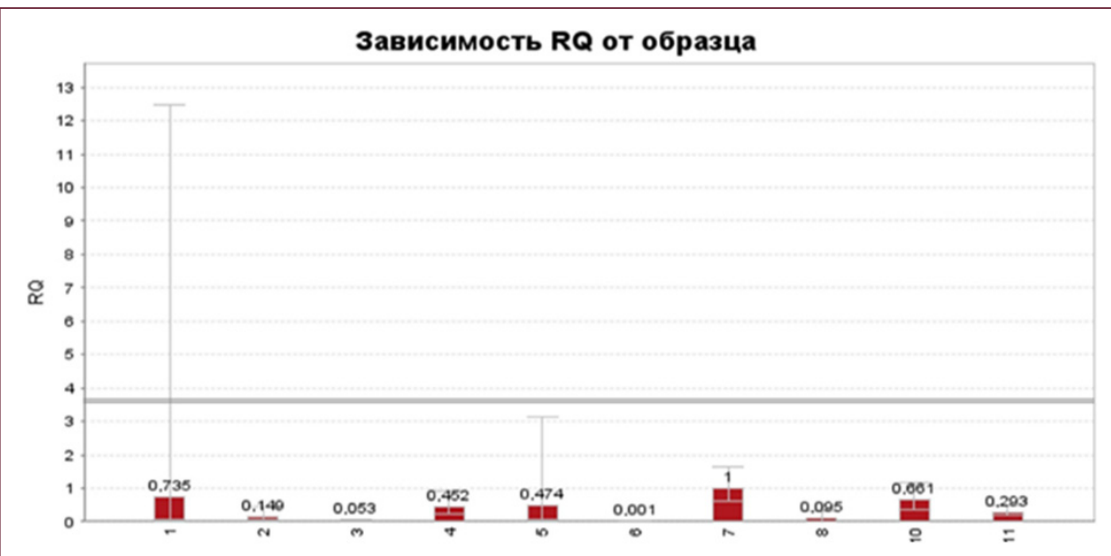

Рисунок 1. 2- $\Delta \Delta C t$ в воронке яйцевода кур несушек породы русская белая бей. Экспрессия последовательности CR523443 в воронке яйцевода у кур с генотипом ТТ составила 0,54, а с генотипом СТ 0,15 (отличия статистически недостоверны).

Экспрессия последовательности CR523443 в матке кур с генотипом ТТ была выше в 49 раз, чем у курицы с генотипом СС (взятой как контроль), а с генотипом СТ в 11 раз; отличия статистически недостоверны (рис. 2, табл. 2). Высокий уровень экспрессии последовательности CR523443 в тканях матки в сравнении с уровнем экспрессии в тканях яйцевода согласуется с физиологией курицы, поскольку образование скорлупы происходит в матке, и, следовательно, ведет к увеличению экспрессии генов, ответственных за формирование скорлупы яйца.

Статистическая недостоверность данных различий, вероятно, обусловлена тем, что экспрессия референсных генов изменялась в условиях эксперимента. Идеальный эталонный ген для нормализации мРНК или уровень экспрессии генов должен быть постоянно стабильным на высоком уровне в большинстве тканей и клеток во всех исследуемых об- 
разцах. Ранее исследователи [8,9] указали на важность использования нескольких генов (минимум двух) для нормализации данных по экспрессии генов. Они продемонстрировали, что более точные результаты могут быть получены, если используется два или более генов, а уровни экспрессии нормализуются с использованием средних геометрических значений. В нашем случае мы использовали гены глицеральдегид-3фосфатдегидрогеназы (GAPDH) и бета-актина (Actb), которые обычно используются как внутренний контроль в количественных исследованиях экспрессии мРНК или белка как наиболее последовательно экспрессируемые гены в разных клетках курицы по сравнению с другими референсными генами, также имеющие название «гены домашнего хозяйства» (housekeeping genes) [10-12].

Полученные данные отчасти согласуются с предыдущим ассоциативным анализом признаков яйца с генотипом, где наибольшую толщину скорлупы и наименьшую упругую деформацию имели гомозиготные куры с генотипом ТТ, а наименьшую толщину и наибольшую упругую деформацию скорлупы яйца - куры с генотипом СС.

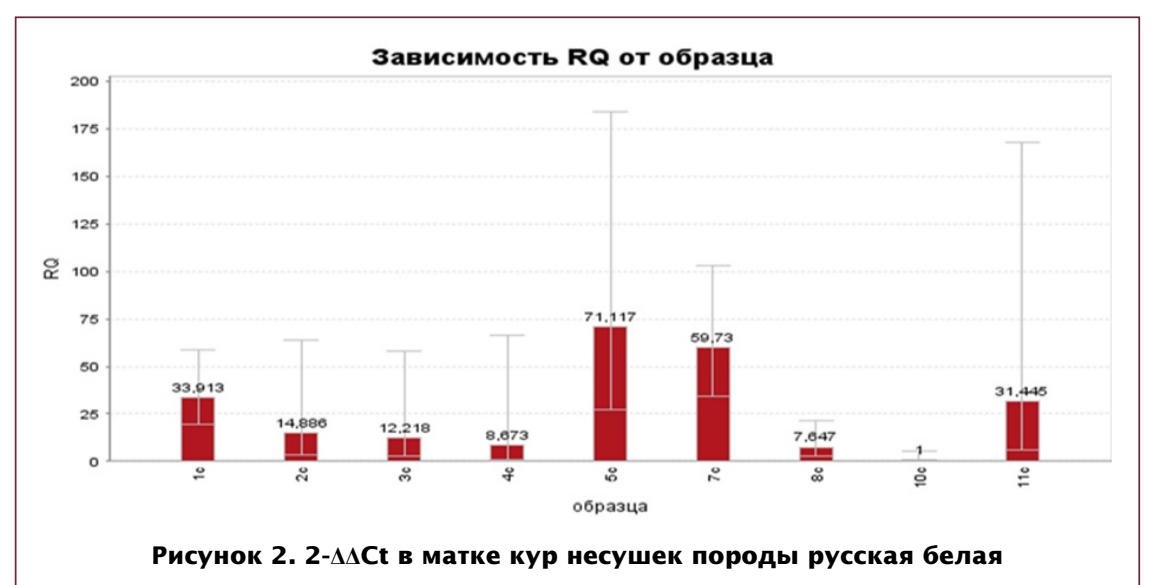

В популяции аврора (137 особей) особи с генотипом СТ имели толщину скорлупы 362,0 мкм и упругую деформацию 20,8 мм; с генотипом ТТ - 379,7 мкм и 18,1 мм; а наименьшую толщину и наибольшую упругую деформацию скорлупы яйца имели особи с генотипом СС (336,2 мкм и 22,9 мм соответственно) [7]. У породы родайленд (96 особей) куры с генотипом СТ имели среднюю толщину скорлупы 351,7 мкм и упругую деформацию 21,4 мм; с генотипом ТТ - 364,8 мкм и 22,7 мм; а наименьшую толщину и наибольшую упругую деформацию скорлупы яйца имели куры с генотипом СС (313,4 мкм и 26,7 мм).

Заключение. В результате эксперимента по изучению транскрипционной активности после- довательности CR523443 была выявлена связь уровней экспрессии данной последовательности с генотипами мононуклеотидной замены 2_1. Наибольший уровень экспрессии наблюдался у кур с генотипом СТ, обладающих более высокими показателями по признакам толщина скорлупы яйца и ее прочность, а наименьший - с генотипом СС; куры с генотипом ТT имели средний уровень экспрессии. Связь уровней экспрессии прослеживалась также с исследуемой тканью кур: так, в матке экспрессия была значительно выше, чем в воронке яйцевода.

В дальнейшей работе планируется предварительная оценка подмножеств кандидатов референсных генов для получения статистической достоверности результатов.

\begin{tabular}{|c|c|c|c|c|c|c|c|}
\hline № курицы & генотип & $\begin{array}{l}\text { Ct среднее } \\
\text { beta actin }\end{array}$ & $\begin{array}{c}\text { Ct среднее } \\
\text { GAPDH }\end{array}$ & $\begin{array}{c}\text { Ct среднее } \\
\text { CR523443 }\end{array}$ & $\Delta \mathrm{Ct}$ среднее & $\begin{array}{c}\Delta \Delta C t(\Delta C t 2- \\
\Delta C t \quad 1)\end{array}$ & $\begin{array}{c}2-\Delta \Delta C t) \\
R Q\end{array}$ \\
\hline 10 & CC & 11,356 & 10,705 & 11,11 & 0,869 & $\mathbf{0}$ & 1 \\
\hline 1 & $\mathrm{TT}$ & 14,236 & 14,343 & 8,19 & $-6,094$ & $-5,084$ & 33,913 \\
\hline 5 & $\mathrm{TT}$ & 13,807 & 14,369 & 6,925 & $-7,16$ & $-6,152$ & 71,117 \\
\hline 7 & $\mathrm{TT}$ & 13,528 & 13,685 & 6,627 & $-6,91$ & $-5,9$ & 59,73 \\
\hline 11 & TT & 13,542 & 12,265 & 6,69 & $-5,98$ & $-4,975$ & 31,445 \\
\hline Х среднее & & 13,78 & 13,66 & 7,108 & 6,53 & 5,52 & 49,05 \\
\hline 2 & $\mathrm{CT}$ & 13,962 & 12,235 & 8,19 & $-4,906$ & $-3,86$ & 14,886 \\
\hline 3 & $\mathrm{CT}$ & 13,553 & 14,178 & 9,24 & $-4,621$ & $-3,611$ & 12,218 \\
\hline 4 & CT & 12,568 & 11,043 & 8,171 & $-4,127$ & $-3,117$ & 8,67 \\
\hline 8 & CT & 14,002 & 12,437 & 8,832 & $-3,94$ & $-2,9$ & 7,64 \\
\hline X среднее & & 13,52 & 12,47 & 8,60 & 4,39 & $-3,37$ & 10,85 \\
\hline
\end{tabular}


Работа Сыполнена при финансовой поддержке Министерстьа науки и Высшего образобания России (Госзадание № $121052600352-3)$.

\section{Литература}

1. Wilson P.B. Recent advances in avian egg science: A review / Poult. Sci. 2017. - V. 96, No 10. - P. 3747-3754.

2. Wardecka B. Preliminary mapping of QTLs affecting egg quality on chromosomes 1-5 in chickens / B. Wardecka, R. Olszewski, K. Jaszczak // Czech J. Anim. Sci. - 2003.- V. 48 - P. 97-105.

3. Sazanov A.A. Expression of positional candidates for shell thickness in the chicken / A.A Sazanov, V.A. Stekolnikova, M. Korczak [et al.] // Poult. Sci. 2007. - V. 86. - P. 202-205.

4. Barkova O.Yu. Design of a system for genotyping of Gallus gallus based on the rSNP (regulatory single nucleotide polymorphism) alleles affecting the eggshell thickness / O.Yu. Barkova, A.L Sazanova, I.Yu Blagoveshenskiy, [et al.] // Russ. J. Genet. - 2011. V. 47, No 2. - P 216-220.
5. Barkova O. Yu. Analysis of the association of a single nucleotide substitution in the intergenic region of chromosome 4 with signs that determine the quality of a domestic chicken egg / O. Yu Barkova, M.G. Smaragdov // Russ. J. Genet. 2013. - V. 49, No 7. - P. 243-247.

6. Баркова О.Ю. Анализ структуры неравновесия по сцеплению однонуклеотидной замены SNP2_1 последовательности CR523443 с близлежащими генами на четвертой хромосоме домашней курицы // Птицеводство. - 2020. - №4. - С.4-9.

7. Баркова О.Ю. Ассоциация однонуклеотидной замены SNP2-1 с признаками качества яйца у кур-несушек // Птицеводство. - 2019. - №7-8. - С. 14-18.

8. Mehta R. Validation of endogenous reference genes for qRT-PCR analysis of human visceral adipose samples / R. Mehta, A. Birerdinc, N. Hossain, A. Afendy // BMC Mol. Biol. - 2010. V. 11. - P. 39.

9. Vandesompele J, Accurate normalization of real-time quantitative RT-PCR data by geometric averaging of multiple internal control genes / J. Vandesom- pele, K. De Preter, F. Pattyn, B. Poppe, N. Van Roy, A. De Paepe, F. Speleman // Genome Biol. - 2002. - V. 3, No 7. - Article RESEARCH0034.

10. Yüzbaşioğlu A. Assessment of housekeeping genes for use in normalization of real time PCR in skeletal muscle with chronic degenerative changes / A. Yüzbaşioğlu, I. Onbaşilar, C. Kocaefe, M.Ozgüç // Exp. Mol. Pathol. - 2010. V. 88. - P. 326-329.

11. Thellin O. Housekeeping genes as internal standards: use and limits / Thellin O., Zorzi W., Lakaye B., De Borman B., Coumans B., Hennen G., Gristar T., Igout A., Heinen E. // J. Biotechnol. 1999. - V. 75. - P. 291-295.

12. Lin J. Histological evidence: housekeeping genes beta-actin and GAPDH are of limited value for normalization of gene expression / J. Lin, C. Redies // Dev. Genes. Evol. - 2012 - V. 222. - P. 369-376.

\section{Для контакта с авторами:}

Баркова Ольга Юрьевна

E-mail: barkoffws@list.ru

Вахрамеев Анатолий Борисович

E-mail: ab_poultry@mail.ru

\title{
The Genotype and Tissue Related Differences in the Transcriptional Activity of CR523443 Sequence in Russian White Chicken Breed
}

\author{
Barkova O.Yu., Vakhrameev A.B. \\ Russian Research Institute of Farm Animal Genetics and Breeding - \\ branch of the Federal Scientific Center for Animal Husbandry of Academician L.K. Ernst
}

\begin{abstract}
Summary: Previous studies have revealed a single nucleotide polymorphism (SNP) 2_l in CR523443 sequence significantly affecting egg quality parameters (egg weight, eggshell thickness and elastic deformation). The aim of the study presented was to check the transcriptional activity of the CR523443 sequence depending on the SNP genotype of the individual chickens and to compare the expression level with the variability of the traits of the eggs in Russian White chicken breed. Analysis of expression in the oviduct showed a significantly reduced level of expression of the CR523443 sequence, in contrast to that in the uterus of the same individuals. Expression of the CR523443 sequence in the infundibulum in chickens with TT genotype was 0.54 while with CT genotype 0.15. Expression of the CR523443 sequence in the uterus of chickens with TT genotype was 49-fold higher in compare to a hen with CC genotype (taken as a control); with CT genotype 11 -fold higher (the differences were insignificant). The data obtained are consistent with the data of earlier associative analysis with egg traits and genotype, where the highest eggshell thickness and the lowest elastic deformation have been found in the heterozygous CT genotype while the lowest eggshell thickness and the highest elastic deformation have been found in the CC genotype.
\end{abstract}

Keywords: chickens, gene expression, single nucleotide polymorphism (SNP), egg quality, eggshell, eggshell weight. 